Tommi Kinnunen, Adjunct professor, National Defence University, Finland

\title{
DEEP LEADERSHIP COACHING EFFECTIVENESS
}

\begin{abstract}
The effectiveness of a coaching process called Deep Lead, deriving from the leadership training of the Finnish Defence Forces, has not been studied efficiently in different civil organisations. This article presents an insight into the effectiveness of this coaching method in two different work communities (PVO-Vesivoima and TAC Finland Inc. Service). The main research question in this article is how to ensure the effectiveness of this particular type of leadership coaching / training. To achieve the best possible results, methodological triangulation was needed in this survey. In this article, two contributing models were introduced (figures 2 and 3) for examining coaching or training effectiveness. By means of these, it can hopefully be examined in the future whether the coaching / training process remains to be a cost, or whether it is an essential investment for the work communities. According to the leadership coaching effectiveness research results of the study at PVO-Vesivoima, such areas as co-operation, interaction and feedback culture were strengthened. As a conclusion, it can be stated that this leadership coaching process works as a practical leadership tool for management in developing the work community both internally and externally. Another example was a work community (TAC Finland Inc Service) that aimed to improve customer satisfaction, evoke know-how, and improve profits by using the deep lead -coaching method. According to the research results, remarkable improvements were accomplished in every field mentioned compared to the time preceding the leadership coaching process or the beginning of the leadership coaching process. In both examples, results were studied using different indicators, different time spans, different methods, and by different reports done by different people. As an outcome of these researches, the leadership coaching process was considered to be effective in PVO-Vesivoima and in TAC, and in the conclusion a practical description of leadership coaching / training or other educational intervention verified on an individual level is introduced.
\end{abstract}




\section{Keywords}

Deep Leadership, leadership coaching / training, leadership coaching effectiveness, organisational development

\section{Introduction}

Traditionally leadership interventions are called training but recently (especially in Finland) it seems that leadership training is called more often leadership coaching (although there are still many similarities in both). In this article the concept coaching is used. The roots of the Deep Leadership ${ }^{\circledR}$ coaching process derive from the leadership training of the Finnish Defence Forces. During many decades, leaders in the economic field have applied the leadership didactics received in the military in their leadership behaviour. Many of them had not received other leadership training before they were appointed as a leader. The leadership training of the defence forces, and the applicability of it in the economic field in civil organisations, has received a lot of interest, but very little research.

This article presents a view on the effectiveness and achievements of the deep leadership coaching process in two different work communities. By studying the effectiveness of this deep leadership coaching method, it can be stated whether coaching can be considered as an investment with a payback time, or purely an expense to lose. This is the main question in many work communities when considering the different options for developing the work community. Therefore stating the effectiveness of the coaching process is important both to the buyer of the service, and to the one offering it. The work communities used as examples in this article are the work communities of TAC Finland Inc. Service (nowadays Schneider Electric Buildings) and PVO-Vesivoima Inc., which is a part of the Pohjolan Voima corporate group. TAC Finland Inc Service took part to the Deep Leadership ${ }^{\circledR}$ coaching process in 2008 - 2009 and PVOVesivoima in 2007 - 2008. Briefly: PVO-Vesivoima is a not-for-profit organisation for delivering affordable electricity to customer owners and TAC Finland Inc. Service tries to be as profitable as possible and strives for high customer satisfaction.

The whole personnel of PVO-Vesivoima took part in the coaching process in four small groups and TAC Finland Inc Service (later on only referred as TAC) in eight small groups. The objective of PVO-Vesivoima coaching process was to improve the interaction culture of the work 
community, and to develop co-operation by means of objectiveorientated interaction. The name of the coaching process was tailored to fit the needs of the work community, and it was called Vesivoima's interaction coaching. The need for the coaching process came from the observation that the organisation seemed to lack a communication culture. In addition, a work satisfaction survey conducted in 2006 at Pohjolan Voima revealed that the results in the areas of the managerial work and well-being at work had decreased compared to the previous survey (the previous survey was conducted in 2004). The objective of the coaching process at TAC was to develop customer services and cooperation through objective-orientated interaction. The coaching process was initiated because of the results of a customer satisfaction survey, conducted by TAC, which showed there were improvements to be made due to the tightening competition situation. TAC had three overall objectives for improvement. These were improving customer service, evoking know-how, and improving profit. To reach these objectives and develop their work community, they chose the Deep Leadership ${ }^{\circledR}$ coaching process, the effectiveness of which has been studied on a general level by Ahoniemi and Kulmala (2008) with good results.

Ahoniemi and Kulmala (2008) have researched the Deep Leadership ${ }^{\circledR}$ coaching process in an immediate superior developmental program in $2004-2007$. The reports of the research project are used in this article (Ahoniemi \& Rytövuori \& Kulmala, 2007; Ahoniemi \& Kulmala 2008; Kulmala \& Ahoniemi \& Nissinen, 2009). According to Ahoniemi and Kulmala (2008), the personal 360-degree leadership profiles of the superiors developed mainly in a positive direction as a result of the coaching process. Also the development of the leadership index, calculated in separate work climate surveys, was mainly positive in these companies. Therefore it can be stated that investing into a high-quality human resources leadership coaching increases work satisfaction among the personnel and improves the actual human resources leadership skills of the superiors. The indices calculated in the work climate satisfaction surveys developed mainly in positive directions in the follow-up surveys conducted after the coaching process. This can be interpreted to mean that the satisfaction in the areas of work climate, managerial work, and communications has increased during the investigated time span. It was clearly stated in these projects that the managerial work and the experienced work climate had a strong reciprocal connection. (Ahoniemi \& Rytövuori \& Kulmala, 2007; Ahoniemi \& Kulmala, 2008) 
It can be inferred from the research results of Ahoniemi and Kulmala (2008; also Ahoniemi \& Rytövuori \& Kulmala, 2007; Kulmala \& Ahoniemi \& Nissinen, 2009) that the work communities seeking growth and profits should well in advance be investing in leadership coaching. The work climate can be improved by coaching those in management, and by doing so avoid the stress and sickness absences caused by resentment. These important factors create satisfaction and commitment as well as improve communication between management and employees. The central objective of companies and organisations, profitability, is determined both by the actions of the work community and the market situation. High-quality leadership coaching can influence productivity, the very factor of profitability that can be controlled by the work community.

The effectiveness of leadership coaching conducted according to the Deep Leadership ${ }^{\circledR}$ method has also been studied in the field of education. Research in the field of education will be completed in the near future, but the most recent completed research is the published master's thesis written by Nikkanen. Nikkanen (2011) studied the effectiveness of the Deep Leadership ${ }^{\circledR}$ coaching process when it was applied to top management (the principal and the dean) of the University of Helsinki. The coaching process was conducted in 2008-2009, during a time when the renewed University Act heavily pressured and challenged the management of the university. According to the research results, the coaching process strengthened the feedback culture, as before the coaching, the highest management had not received sufficient feedback on their own behaviour. The coaching process offered the management certain tools to enhance their self-knowledge and to develop their own leadership.

The central objective of the Deep Leadership ${ }^{\circledR}$ coaching process (DL, 2010) is to assist people to develop themselves in the critical evaluation of their own behaviour and enhancing their own interaction skills. The underlying belief is that individual learning must precede the development of a team, group, unit and the whole organisation. The Deep Leadership ${ }^{\circledR}$ coaching process, including learning assignments (These are tasks provided in Word format that may help a person to develop, for example their development plan, a work environment analysis, learning diary etc.), is presented in figure 1 . In addition to the 
importance of contact days for coaching, marked in red in the figure, the value of the learning assignments done outside the coaching situation is at least as consequential. The critical points concerning the coaching effectiveness have been marked with circles. The coaching process is a path guiding for learning where the relevance of systematic encoded feedback and enlightening others about the contents of one's development plans are central. No-one can develop interaction skills in secret. Therefore, articulating one's plan to others determines the amount of support the person gains for his or her development (Kinnunen, 2006; 2008; 2009).

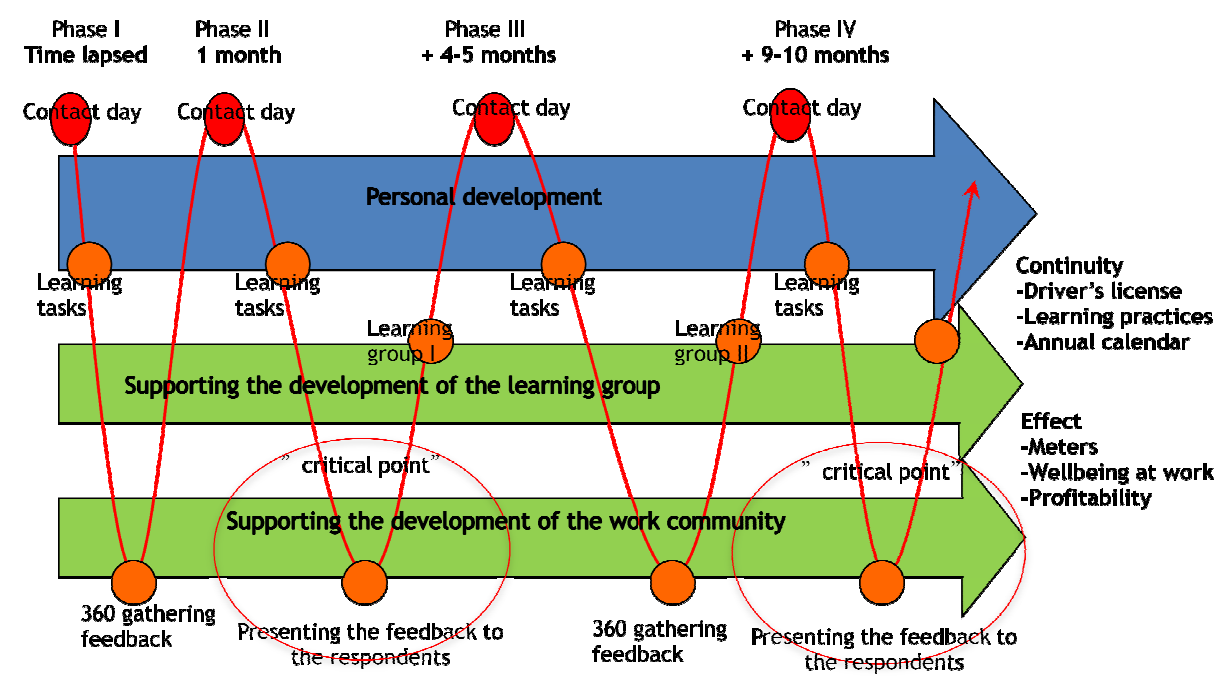

Figure 1. Deep Lead ${ }^{\circledR}$ coaching core process (DL 2010)

The Deep Leadership coaching core process is divided into three levels. At the personal development level the participant evaluates his or her strengths, weaknesses and how he or she has developed during the coaching process. At the next level, people are put into learning groups where the aim is to support each individual's development. The last level is the work community. This is when participants gather and present feedback from the most important people who can support and challenge their development. The feedback tool they use is called DLQ (Deep Leadership Questionnaire, from now referred to as the 360-profile). It has 30 questions and three open questions where the respondent can evaluate freely the person who is being assessed. A profile is gathered from the 
answers of the superior, peers, subordinates and from the self-evaluation. These profiles have a very important role in the evaluation of learning and coaching effectiveness. The main topics during the contact days are: goal-oriented interaction, interaction behaviour, the 360-profile and the development plan, values and follow-up of the 360-profile with the updated development plan.

\section{Leadership Coaching/Training effectiveness}

The main research question in this article is how to ensure the effectiveness of the leadership coaching / training. To achieve the best possible results, methodological triangulation was needed in this survey. The data is presented further on. A thorough evaluation of coaching focusing on leadership or interaction skills is difficult. This type of evaluation is especially difficult, as no human being lives in a vacuum. A human being is affected by many different factors, and therefore development happens regardless of coaching. The best results in coaching effectiveness are accomplished if the situation is examined before, during, and after the coaching process. Consequently it is important to use different valid independent indicators and cross examine the results to get a general overview. That is why this research was conducted by methodological triangulation, in which the same phenomenon is examined by different methods and indicators (Kinnunen, 2010A \& 2010B).

Westley (2005) has explored the effectiveness of leadership training on adult learners. One evaluation concentrated specifically on leadership and communication training. An electronic survey data was collected from the participants who attended training between 1988 and 2004. Westley's results demonstrated that participants found the course instruction effective, the course met their expectations, and that they acquired leadership competencies were used in a variety of settings both in and out of the workplace. Another significant relationship was found between the importance of job performance and perceived skill improvement in the leadership competencies taught in the workshop. Research failed to show any significant difference in mean scores across all sixteen years, suggesting that effectiveness and satisfaction have remained constant over time. In this article, one of the aims is to evaluate how the 
effectiveness of leadership coaching demonstrates itself in the years after coaching.

Mäkitalo and Turunen (2008) state that the randomized controlled trial (RCT) as a method of effectiveness evaluation has attained gold standard status in verifying effectiveness. This experimental design requires that the experimental group in question is a representative sample of the population which the results are proportionate to. The experimental group should be homogenous in terms of the phenomenon being examined, and the content of the intervention should be independent from the target group. The content of the intervention should be equal to or the same for all participants, and it should be blinded. However, in social interventions (coaching, training, supervision, development etc.), none of the criteria mentioned above is realized. Samples are not representative but merely targets of an intervention [gathered] through multiple selections. In this kind of situation, selecting control groups is very difficult, if not impossible. The interest is not in any specific natural scientific phenomenon, but in overlapping abstract concepts, such as learning, interaction, feedback, that are dependent on signification and interpretation. The interventions are interactive and formed, at least to some extent, along with the target group's needs and responses which vary according to the group or individual. Blinding is not possible either, as it is impossible to hide the "missing element" from the target group and from those implementing the intervention. (Mäkitalo \& Turunen, 2008.)

Engeström, Kerosuo and Kajamaa (2008), too, state that evaluating effectiveness is challenging, and recommend exploring causes rather than effectiveness. In causal studies the focus is on predicted and unpredicted long-term causes as one strives towards development. Causal studies recognize both the factors of the causes, and the actual causes, that trigger a change that is connected to the implemented interventions. Examining the cause paths in the project means that the focus is on the connections between the objects, acts and incidents, participants, tools and occupational context occurring during the project. Causal studies offer a possibility to examine continuity / discontinuity in development. Continuity and discontinuity are precisely the central concepts in examining organisational change and development (Engeström \& Kerosuo \& Kajamaa, 2008). In this article, I will consider the practices 
and phenomena of coaching effectiveness that occurred after coaching in PVO-Vesivoima and TAC, and which are seen as permanent.

According to Engeström, Kerosuo and Kajamaa, the problems and challenges of causal studies reflect the nature of change in working life. The changes in organisations and in work in general are broader and more difficult to confine. The basis of causal studies is the effectiveness vis-à-vis the objectives set, and is therefore conducted on the assumption of causality: operations executed consciously create desired outcomes. However, the realized effects are often very different from the objectives. The effects are formed by the inconsistent interconnections of many conscious and unintentional factors, the precise and specific reasons of which are impossible to track down. (Engeström \& Kerosuo \& Kajamaa, 2008) According to Mäkitalo and Turunen (2008), the evaluation of effectiveness should consider more often what kind of intervention effectiveness is under investigation, and what kind of methods are being used for affecting the phenomena. Only after this is it reasonable to consider what kind of methods should be used for evaluating effectiveness. They recommend that the ideal of idealise one best method should be abandoned and that effectiveness should be evaluated with methods best suited to the phenomena and the nature of the intervention; always in a systematic and critical way - obeying the best traditions of science. They believe that this is probably the closest we can get to certainty.

\section{Model for considering coaching effectiveness}

Figure 2 presents an applied version of the effectiveness evaluation model by Kinnunen and Nissinen (2009), where the attainable coaching effect can be divided into internal and external effects in the work environment. The more the work community members participate in the coaching process, the more rapidly and successfully the process will proceed from the inner circles to the outer ones. The fastest and most effective results are accomplished when all the members participate in a common improvement by changing their own behaviour, and when free riders are only a rare exception. In some situations the levels of effectiveness can be folded in a way that some of the levels never exist. For example, the immediate effects can be accomplished, but the difficulties in individual relations and persuasions remain and hinder the accomplishment of mediate effects. In practice this may be seen in the 
internal success of individuals and teams, but it is possible that even strong contradictions occur between them. These contradictions do not necessarily have an effect outside the work environment, and therefore positive effectiveness might still appear at the reflective level as well as at the level of interest groups. The inner contradictions or problems in the work environment might not be visible to the external (e.g. customers) actors (unless individuals break rank to speak about them). (Kinnunen, 2010A \& Kinnunen, 2010B) This article shows how to measure effectiveness by analyzing the results at every level.

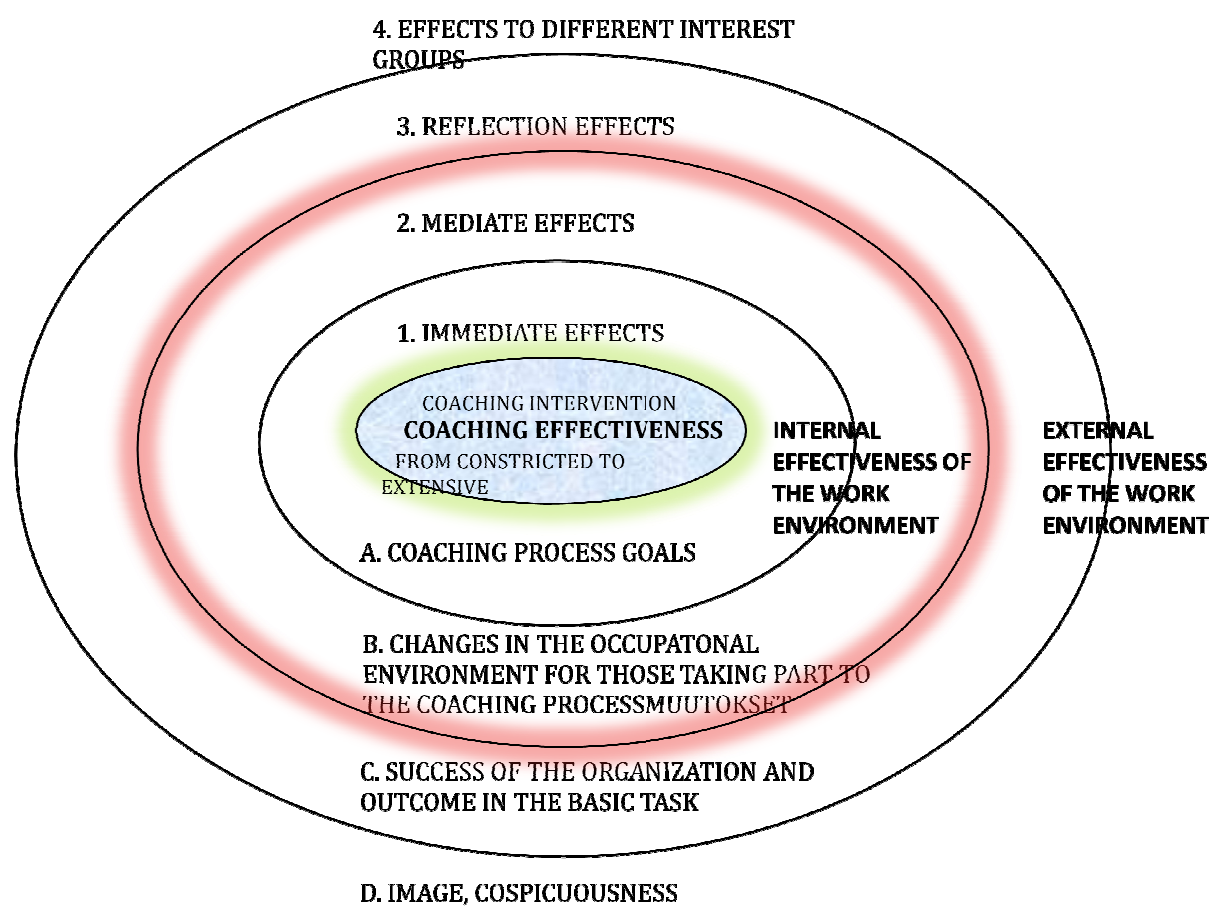

Figure 2. Coaching effectiveness (Kinnunen 2010A \& 2010B; see Kinnunen \& Nissinen 2009)

Coaching effectiveness (Kinnunen, 2010A \& Kinnunen, 2010B; see Kinnunen \& Nissinen, 2009) can be viewed from an individual, group or organisational perspective in the reviewed model. The effectiveness of coaching is evaluated according to the extent of co-operation and using indications that are agreed on in advance. Typically the evaluation concerns the immediate and mediate effects. Therefore, the effectiveness 
is being evaluated within the work environment; thus the concern is internal effectiveness. The external effectiveness consists of effects in interest groups and the reflection effects. In other words, the people outside the work environment notice effectiveness in the actions performed by the members of the work environment. The following includes a more detailed description of the levels in figure 2 and the typical metrics or indicators used:

A) Goals of the Coaching Process (immediate effects)

- meters e.g. changes in the profiles, coaching feedback, learning assignments, effectiveness survey

B) Changes in the occupational environments (mediate effects)

- meters e.g. the work community's own employee and climate surveys

C) Organisational success and outcome in the basic task (reflection effects)

- meters e.g. tools for evaluating the basic task (customer satisfaction surveys, balance sheet, business branch comparisons)

D) Image, conspicuosness (effects in the interest groups et cetera)

- meters e.g. brand and image surveys by exterior quarter (someone outside of the business)

The levels mentioned above correlate with each other so that often the good immediate effects translate into good mediate effects. The same principle applies from the core components to the outer circles. In order to obtain the reflection of the effects at the interest group level, it is essential that attendance at coaching is high enough. A few people in a large work community are not enough for a big development process which demands cultural and procedural development. This is founded on an individual's solitary ability to change his or her behaviour. Although these changes have reflection effects on the surrounding people, the longlasting modifications are attained only with personal work towards individual change. (Kinnunen, 2010A \& Kinnunen, 2010B) The model described above is in accordance with The Kirkpatrick Model (1998) of classical effectiveness, which consists of four different levels: reactions, learning, behavioural changes, and results. The model in figure 2 stresses a separate examination of effectiveness within and outside the work community as a new viewpoint. Too often one settles for only the changes happening and measured within the work community in coaching effectiveness. Verifying the effectiveness outside the work 
community is challenging if comparable information does not exist and extend some years back, or the indicators are not valid, giving, according to the worst scenario, distorted information about the reality.

\section{Results}

The research results are divided into subtitles according to the circle structure of effectiveness. Mindcom is administrating the 360-profiles of the Deep Lead Inc., and has completed the statistical comparisons of the profiles using the SPSS statistics programme. Statistically significant variances in the 360-profiles have been tested with the student's t-test. Also the differences in the results in work climate surveys at Pohjolan Voima in 2006 and 2008 will be explored. Our analysis will also be able to draw on Yhdyskuntatutkimus's research on PVO Vesivoima's company image and an opinion survey on the company's energy policy in the occupational environment, both conducted in 2009. The material and texts of this article were shown to PVO-Vesivoima Inc. CEO and management so that the information and analysis concerning the company and coaching are consistent with their views about reality. In TAC, their climate surveys, economical profit comparisons and results in customer satisfaction surveys are explored as well. TAC materials were also shown to the management, to check the facts related to the surveys.

\section{Immediate effects}

This section is on the immediate effects of coaching by means of changes in the profiles, as well as on coaching feedback. During the one-year coaching process (with PVO-Vesivoima and TAC) every participant completed learning assignments during the time between the contact days. The learning assignments were mainly informal essays and learning diaries, so in this research they represent the qualitative research material. The learning assignments were mainly carried out independently, except the two learning group assignments which were done together in the smaller learning groups. The learning assignments were confidential, except the personal developmental plan. The work environment analysis often includes information that is intended to be used within the company only. The learning assignments were analyzed using the method of content analysis. In addition, every learning assignment was compared to the corresponding changes in the personal profile. A clear connection between the two was found. The broader the person's reflection on their 
behaviour, the more changes could be perceived in their profile. Most of the participants were not used to analyzing their own behaviour in written form, which could be seen as brief answers. The coaching process seemed to develop people's preparedness to critically evaluate their own behaviour, as the extent and content of the learning assignments seemed to evolve towards different layers in the circle. However, some people kept their responses to a minimum throughout the coaching process so that the profile changes remained slight or even regressed in some cases. This observation strengthens the impression that the development of a person's behaviour requires long-term support.

In the learning assignment, those participating in the coaching were asked to evaluate the changes in their own behaviour, and the changes they had noticed in the behaviour of other people. In the independent discussions, people tended to be very critical towards their own behaviour. People would quite often speculate whether their own behaviour had changed at all during the coaching. The changes in the behaviour of others' were more easily noticed. This exact phenomenon was discernible both at PVO and TAC when the profile changes were examined by answer groups. The changes were considerably small in self-evaluations but then remarkable when made by others. The developmental plan was part of the learning assignments, which was conducted by those taking part in the coaching process after the profile analysis. The focus of the developmental plan was on personal development, in other words, the change in the selected dimension described in the developmental plan gave indications of about how the person had managed to act according to the developmental plan. In practice, progress on the developmental plan was monitored during and after the coaching process by assessing realization of the developmental clauses. This applied to both companies (PVO-Vesivoima and TAC).

In 2007 - 2008 the profile changes at PVO-Vesivoima were statistically highly significant $(* * *)$ using the t-test in every dimension of the deep leadership model. These measurements were included in the coaching process, and therefore the comparison in $2008-2009$ describes the situation and changes a year after the coaching. The challenge often is that a good start towards a positive change during a coaching process stops, and the old policies return. It now seems that the positive changes that were statistically significant were successfully received within those dimensions (inspirational motivation, learning and trust), that had also 
ended up in the developmental plans. According to this result, the realization of the developmental plan over a long time span causes the statistically significant development. (Kinnunen, 2010A)

In an overall comparison of the TAC profiles, only the results in leaders' self-evaluations in controlling leadership dimension turned in a negative direction, in other words, increased in the re-evaluation values. In other ways, the changes were of the desired kind, as the values had increased in re-evaluation. When the leader and personnel evaluations of the TAC were combined and the statistically significant changes were examined, the development was clear. The positive changes were statistically significant in every dimension according to the t-test. A more explicit examination revealed that the background to these big changes stemmed from notable changes in personnel profiles, where positive change was highly significant $(* * *)$ in every dimension. The change among leaders was not as remarkable. The statistically significant positive changes were, however, discovered in five different dimensions (individual consideration, learning, inspirational motivation, extra effort and effectiveness) as well as in the leadership index. Minor changes in control and passiveness can be explained with fairly positive starting points and therefore it was challenging to reach significant improvements. (Kinnunen, 2010B)

The people at PVO-Vesivoima were critical of their own changes, and underestimated themselves in the evaluations. Most of them have worked for PVO- Vesivoima for 10 to 30 years, and the reason they were critical may have to do with them having false impressions about unchanged behaviour. The possibility to make permanent changes in a person's behaviour in a one-to-three-year time span might have not been realized. On the other hand, the results received are a reminder of the importance of the feedback. If we had only used self-evaluations to assess possible change, the development and thereafter the effectiveness of the coaching process would seemingly not have taken place. According to the experiences of other people, however, the situation was quite the opposite, as demonstrated by the t-test which showed that the changes were statistically highly significant in many areas. This change is, however, based on results using only one indicator and a three-year time span, and therefore the change must also be analyzed in the light of other indicators. 
During the first examination period $(2007$ - 2008) in PVO-Vesivoima, the superiors and the peers of those being evaluated perceived equally many positive changes in the behaviour of the people being evaluated. The third most development was perceived by subordinates and partners, and the least by the evaluated persons themselves. During the second evaluation period $(2008-2009)$, the peers perceived the most change continuing in the behaviour of those being evaluated. In second came the subordinates and the peers, whereas the superiors did not perceive such a statistically highly significant positive change (t-test) during the second evaluation period. Again, the least development was perceived by the people who were being evaluated. To summarize, it can be stated that the most significant changes were perceived by the peer group, and the least significant in the self evaluations. Because the whole work community took part in the coaching, most of the participants belonged to teams, having no superior responsibilities. This could possibly be considered as one of the denominators, explaining why the changes were perceived clearer in the peer evaluations than in other groups.

On the other hand, within the TAC work community, the development of the superiors was perceived the best by their subordinates, whereas among the rest of the personnel, the peers were the feedback source perceiving their development best. The second highest feedback source within both of cases was self evaluation. This means that those being evaluated think themselves that there would have been ore development than what the two other feedback sources perceived. A clear difference can be perceived between these results in TAC and PVO-Vesivoima. One explanatory factor might be the shorter employment relationships in $\mathrm{TAC}$, as it might be imagined that development would be more significant and happen faster. The superior of those being evaluated did not appear to perceive change as much as the persons themselves. When considering the leadership profiles in TAC, the smallest changes were perceived by the peers. This can be explained by the job descriptions of the superiors, as the amount of time spent with peers is remarkably shorter than the time spent with subordinates. Among the employees, the partners / customers were the group that perceived the least change. This can be explained by the fact that it is so rare that the employee works with the same customer that perceiving a statistically significant change could not actualize within the examination period. When considering the overall profile changes at TAC, the superiors did not manage to develop as much as other personnel (Kinnunen, 2010B) 
Typically the effectiveness of a coaching process is examined by the feedback given during the coaching process. Visible effectiveness might take from several weeks to months, and therefore the image of effectiveness immediately after coaching might be wrong. Reactions might be good, but do not guarantee learning, or results. On the other hand, without positive reactions the other Kirkpatrick's (1998) levels of effectiveness are not accomplished. The feedback on the coaching process at PVO-Vesivoima and TAC was collected anonymously, so the change in individual commitment during and after coaching could not be examined. Because individual persons changed groups between different phases, on a group level the change can be examined only on a broadminded level. The mean value of all the phases in groups was 4.1 (on a scale from 1 to 5). Differences between groups appeared in commitment to individual development. Even though an exact comparison on an individual level in commitment to developing oneself is challenging, indicative observations can be completed with group results. At each phase, the lists of the names of the participants in different groups were accurate, and by examining both the lists and the learning assignments, a relation between these factors could be perceived. According to the contents of the learning assignments, the commitment to personal development seemed to be influenced by perceptions of change in other people's behaviour. The learning assignments showed that discovering co-workers' steps of development to be encouraging. The coaching process progressed phase by phase, so it can be that commitment to personal development would grow. However, it was noticed that commitment did not increase automatically. According to group feedback, it could even decrease. As to the total evaluations of the feedback of the coaching process, they lived their own life and were not ascending either in PVO-Vesivoima or TAC.

When all TAC Service's (superiors and other personnel) feedback changes were combined, excellent results were received. The changes in every dimension were statistically highly significant according to the ttest. However, there were differences found in the background. The overall evaluation of the coaching seemed to be very close to commitment to personal development (comparing coaching feedback). If the coaching phase was experienced positively, the commitment to personal development was also better. This suggests that the quality of the coaching process is an important factor when considering the 
effectiveness of a coaching process. Comparing the different phases, none of the groups had ascending mean values for the coaching feedback. The same phenomenon was visible in the material from PVO-Vesivoima. This indicates that the nature of the deep leadership coaching process is not ascending, which would increase the participants commitment in their personal development. But as content of the coaching process, the different phases of the coaching process live their own lives. For example, different coaches and expectations of the participants act as change factors, and therefore a coaching process, although standard in content, can change according to the coach and the participants. One explanatory factor is the time span of the coaching. Contact days need to take place often and regularly so that commitment can be kept high/ascending. Job stress and busy at work challenge the ascending development, thus decreasing the level of personal development observed over a long-term time span.

\section{Mediate effects}

This chapter is a review of the mediate effects of coaching. PVOVesivoima has conducted work climate surveys among their personnel every two years. The focus of this article is on the situation before the coaching process (the work climate survey done in 2006) and the situation during the coaching process (spring 2008). Compared to the previous work climate survey, there had been positive changes in the how personnel at PVO-Vesivoima perceived their work place in 2008. The amount of those motivated to work ("ambassadors" in the questionnaire) had increased by 8 per cent, whereas the amount of frustrated employees ("estranged") had decreased by almost as much ( -7 per cent). In addition, the amount of critics had changed, decreased (- 4 per cent), and the amount of so-called reservists increased by 3 per cent. The percentual change among those motivated was immense compared to the Pohjolan Voima corporate group and other work communities in Finland. The initial situation at PVO-Vesivoima was already excellent, and very strongly it became even better. In the work climate survey there was also a more general index number (TRI*M) to describe the level of commitment. According to the interpretation instructions, if the number was below 40, the index number was considered low, the average was between 40 and 70 and the high values were above 70 . Hence, the corresponding index numbers were (in 2006/2008): the Finnish average (56/57), Pohjolan Voima corporate group (66/65) and PVO-Vesivoima 
Oy (76/81). As the index numbers indicate, PVO -Vesivoima was a high quality work community already in 2006. Still it was able to improve the commitment of its personnel even further. (Kinnunen, 2010A).

The PVO-Vesivoima work climate survey included a total of 74 statements which were answered on a scale from one to five. According to the interpretation instructions of the climate survey, a change of over 0.2 since the previous study (2006) is a significant change. A significant (changing more than 0.2 ) positive change occurred in a total of 39 statements (being 53 per cent of all the statements). The most significant change since the previous survey occurred in the negative issues (bullying at work and uncertainty had decreased outstandingly). In all, these significant changes concerned well-being at work, leadership, work climate, co-operation between people, information flow, solving contradictions and commitment to work. There was a decrease in six statements (e.g. work induction, co-operation between the different companies of the corporate group, rewarding system, and equal appreciation of work regardless of age. A significant decrease occurred in one statement: my work and free time are in good balance $(3.88=>3.59$, change -0.29$)$. One starting point in the coaching process was the results of the work climate survey in 2006, where the challenges of well-being at work and motivation emerged. To the statement mentioned before, a contradictive view of situation is offered by the significant changes of the following statements: I am ready to work long days if my work tasks requires it $(3.93=>4.54$, change $+0,61)$, I feel that I have enough resources to cope well with my work tasks now and in the future $(3.50=>$ 4.05 , change +0.55$)$, the pressure of work has increased during the last year $(4.14=>3.86$, change -0.28$)$. According to the results, it seems that the respondents wish for more free time, but are willing to be flexible according to the wishes of the employer, while still maintaining their well-being at work. (Kinnunen, 2010A)

PVO-Vesivoima was successful in the work climate research in 2008. PVO- Vesivoima had five good fields (mean value over 4.0), when the whole Pohjolan Voima corporate group had none in the mean value results. According to the research done in 2006, the results at PVOVesivoima were on the same level as in the whole corporation in 2008. In 2006 PVO-Vesivoima had no good fields at all (on the other hand, no weak ones either), and in 2008 the amount of good ones was already 36 per cent. (PVO-Vesivoima Inc Work Climate Research, 2006 \& 2008) 
When considering the immediate effects in the work community of PVOVesivoima, comprehensive development did occur, and in the light of the previously introduced comparative results, it seems to indicate that also the mediate effects of the coaching process can be seen. The fact that the greatest changes had occurred in those exact areas that were the objective of the coaching process supports this observation. Different indicators showed great improvement in mediate and immediate effects when the situation was compared to the before-situation or to situation at the beginning of coaching. According to the model of effectiveness, it can be stated that it seems that the coaching process has been effective, at least when studying the work community of PVO-Vesivoima internally.

To examine the mediate effects in TAC, I have drawn on the personnel surveys (PeopleScope and OneVoice) commissioned by TAC as well as on sickness absence follow-ups, as they give a rudimentary picture of personnel well-being. During the years of observation (2008 - 2010), sick leaves decreased by a total of 1,481 work hours in TAC, corresponding altogether to 198 work days. This, in turn, is nearly a whole year of work for one employee. If in a work community of about three hundred employees the sick leaves could be decreased by one year of work of one employee, this could be considered as a good trend. As TAC Finland Oy merged with the Schneider Electric corporation in 2009, the OneVoice survey used in Schneider Electric replaced the People Scope employee survey. The results of the OneVoice survey remained on a nice-to-know level. The examination of the coaching effectiveness is hindered by the fact that the service groups are a part of Buildings Finland group. As mechanics and sales are also part of this same group, the results cannot be used as such in this article. The results at Schneider Electric Finland were used as a comparison. All the results are approximately 10 per cent better within Buildings Finland (BF) than in Schneider Electric Finland (SEF). As a whole, the PeopleScope questionnaire (TAC Finland Inc's work satisfaction survey for 2008) shows that people experienced things they could influence themselves as positive (for e.g. co-operation with others) evaluations. The developmental needs were found mainly at an organisational level (e.g. rewarding and the work processes). The mediate effects at TAC could not be specified as clearly as at PVO-Vesivoima where it was possible to concentrate on the changes taking place within the work community by using comparable indicators (work climate surveys). In TAC, the mediate effects concerning the work community were inferred from the decrease 
in sick leaves. There were month-specific differences (e.g. holiday seasons, religious holidays) in sick leaves, and therefore each month was compared with the corresponding month of the previous year.

\section{Reflection effects}

The primary task of PVO-Vesivoima, which is a nonprofit organisation, is to deliver affordable electricity to its owners. Therefore it is not meaningful to consider the reflection effects in the light of economical parameters. In this research, the reflection effects were observed by comparing branches. PVO Vesivoima's image was analysed by Kiljunen (see Kiljunen 2009, Yhdyskuntatutkimus Inc.) in 2007 and 2009, so first before Deep Leadership coaching and then a good half year after coaching. He also studied PVO Vesivoima's employees' views on the company's energy policy. Kiljunen's research results will be used in the evaluation of the reflection and interest group effects. Kiljunen's (2009) results were collected using a written questionnaire between 28 April and 6 June 2009. The target group consisted of 2,925 people aged 18-70 living in PVO Vesivoima's area of operation, collected randomly from the central register. Unfortunately, there was considerable item nonresponse; only 605 forms could be analysed. Even so, the results can be considered as indicative.

When interpreting the research results of Kiljunen (2009), one should notice the nature of PVO Vesivoima as a company. It is not connected straight to the consumer so, unlike other companies, it does not need to have such high visibility among the general public because it is not trying to sell a product to a large amount of customers each day. However, because of social relations, reputation, the ability to recruit, and the factors related to those occupational requirements, visibility is naturally necessary for all companies. Pohjolan Voima / PVO Vesivoima rose to top results in the comparison (Kiljunen 2009). The Kollaja Project produced a very colourful, and strongly sentimental, public reaction against the project between 2007 and 2009. In this situation, the positive result of PVO-Vesivoima in visibility and the favourable images strengthens the results reported in contact with the mediate effects (e.g. information flow, co-operation, solving contradictions), are excellent achievement. 
Reflection effects at TAC are analyzed using customer satisfaction surveys and by comparing financial statistics. The answers became polarized when the customers of TAC were asked, "How would you describe the development of our mechanics during the last year?" 31 per cent of the answers stated that there were no positive changes, but rather a decrease in quality. Twenty one per cent pointed out they perceived no change whatsoever. Thirty seven percent had perceived development for the better, emphasizing improved customer service and willingness. The rest of the respondents settled for non-specific answers, for example commenting that the mechanics consists of "proper guys", or mentioning that the machinery has functioned well and that there had not been any need for mechanics during the past year.

When comparing the economic parameters, TAC's independently conducted annual comparisons in turnover and sales margin during the years $2005-2009$ were used. The year 2007 was the last sales year before coaching, which took place during 2008 and 2009. Coaching effectiveness can be noted to some extent during 2008, but during 2009 the effects were much more noticeable. Until the end of the year 2008 some of the business areas experienced a negative change in TAC's economy, but during 2009 the economical development improved considerably in all the areas compared to the previous year. The development of the sales margin was particularly good and improved 19.8 - 79.1 per cent depending on the region (total 33.6 per cent). These key figures do not necessarily speak directly for coaching effectiveness, but according to the results in the customer satisfaction interviews (customer satisfaction survey at TAC Service), some customer procedures had improved. Earlier, mechanics would visit the customer without the customer even noticing. Now mechanics report what they have done and repaired. At the same time, mechanics offer supplementary services or answer customer's questions. This means calls have decreased and that customers actually get the service they need when the problem occurs. This made co-operation between TAC and the customer more straightforward and increased the sales margin.

Therefore, it can be stated that customer satisfaction and profit can be increased by interaction, at least partially. One can only speculate how big the improvement would have been without Deep Lead ${ }^{\circledR}$ coaching. Having said that, there were slight decreases in turnover and sales before coaching (in 2007, when the economy was still doing well) but profits 
have grown since all over Finland - despite the recession. (Kinnunen, 2010B)

In this article the customer satisfaction survey summary at TAC Finland Oy Service 2009 is examined. The baseline is the situation before coaching in 2007. The survey was conducted by a neutral company (Mercuri International Inc.) and according to the interpretation instructions for their report, the improvement of 0.2 in total is rare, and therefore represents a significant change compared to the previous measurement. The TAC Service organisation succeeded even better than that, reaching a total of 0.22 of improvement. The most improvement occurred in the mean values of the following statements: Customer receives information from the mechanics on how certain problems can be avoided; [T] he mechanics offer suggestions for future improvement for solutions used by the customer; [T] he mechanics at TAC Finland are skilful and technically qualified. Improvement of skills was one of the three objectives at TAC, which the coaching process focused on. The improvement in know-how was successful as it could be seen reflected in customer responses and translated into a great change of the mean value for the statement The mechanics at TAC Finland are skilful and technically qualified. The greatest changes in Service Department were related to customer service (how the customer avoids problems and receives suggestions for solutions), at which time customer satisfaction was improved even more. (Kinnunen, 2010B)

\section{Effects on the interest group}

Kiljunen's (2009) report is further taken advantage of in the PVOVesivoima interest group evaluation. I will look more closely at the different elements of company image and evaluations of PVOVesivoima's social and environmental responsibility. The results in company image characters formed to be positive in general. According to Kiljunen's (2009) research the character profiles forming of the results were greatly alike to the ones drawn in the pr-department (statements that were suitable for describing the company very well, were positive, and other end were the negatively toned descriptions, which the respondents thought did not describe PVO-Vesivoima well). The top places in the profiles took the statements operates tasks well (61\%), big tax payer (60\%), company with a good reputation (57\%) and modern and dynamic (54\%). The answers concerning the good reputation of PVO-Vesivoima 
were reflected not only in the personal views of the respondents, but also in the views of other's, in how the matter is experienced collectively. If the predominant thinking would have been labelled by some more general suspicion or mistrust, let alone resentment, the distributions would not have formed (Kiljunen, 2009).

The changes in the company image characters of PVO-Vesivoima were examined from the year 2007 to the year 2009. According to Kiljunen's (2009) research report, the general image of the company was fmore positive than before. Even though the transitions are not great, they occurred systematically throughout the resulting profile. In practice, all the better suitable qualifiers for PVO- Vesivoima, compared to the previous survey, were positive in character, and the ones viewed as less suitable were negative. The most significant in adding insight to the positive characters (especially when the change values at both ends of the distribution in the change are observed) were: modern and dynamic, operates tasks well, environmental responsibility, remarkable employer, big tax payer and takes good care of societal relations. The most remarkable loss in suitability occurred in the following statements: have been left behind modern times, boring field, is not interesting / does not attract young talents, unnoticeable, withdrawn from the public discussion, passive, careless in environmental protection, only concerned with economic values and forgets the social and environmental ones, and careless towards the opinions of citizens. Kiljunen (2009) reports that on the whole, the changes were only positive. In content they were formed from heterogenic substance to the extent that the matter was more in general development than only about change in some certain parts (strength or weakness). (Kinnunen, 2010A)

The effects on the interest group were reflected in the results in the customer satisfaction survey at TAC service organisation (2009). Industry comparisons leaned towards the open question whether TAC Finland Inc is superior to its competitors. There was some dispersion in the answers so that 9 per cent did not think TAC was better than its competitors. About a quarter (26\%) could not compare or give an answer. Most customers (65\%) could gave positive examples to show TAC as being better than the competing companies. Fast service, expertise and good co-operation got the most acknowledgements. The differences between TAC and the competing companies were also surveyed by phone interviews. This was done to customer community influencers, to 
whom the following questions were asked: "How would you describe TAC mechanics compared to other performers in the field?" and "Where is TAC better than competitors?" The interviews brought up very similar answers than the open survey. Compared to the survey, the difference in the interviews was that there was a total lack of negative comments. Six out of eight (75\%) saw TAC as being better than its competitors. Again expertise, reliability, fast service and service willingness were brought up. Flow of information was also perceived as a strength.

\section{Summarizing the research results}

With the multilayered effectiveness levels in this article, it was noticed that among the Deep Leadership coaching process and the strengthening of the interaction culture in the work community, the success of the work community is strengthened when evaluated internally as well as externally in PVO-Vesivoima. Extremely positive reflection and interest group effects cannot, however, be enthroned only as a coaching merit. Committed management played a big role in changing the procedures and developing the interaction culture by showing an example and by forming more open and conversational policies. The coaching helped individuals on a practical level to behave in a more conversational way, but the management's decision - made by corporate - to change the company's policies played a very crucial role in brining about positive change. The perception of Birger Ylisaukko-Oja (2010), the CEO of PVO-Vesivoima's, during the coaching process about the reasons of the change of the company and about the change itself, supports the beforementioned. As a conclusion it can be stated that the coaching has functioned as a practical tool for management and as an aid for leadership in the internal and external development of the work community. In PVO-Vesivoima's case, an independent party (Yhdyskuntatutkimus) who conducted research on effectiveness noted significant changes in other peoples' evaluations in between 2007 and 2009 (Kiljunen, 2009). By studying these results it was noticed that the reflection and interest-group effects were seen on a very broad front instead of as only individual changes in small areas.

Success (statistically significant development according to the t-test) in 360 evaluations at TAC seemed to predict success (positive development) also in financial profits and customer satisfaction. Know-how was improved [by coaching?] according to the customer opinion as well as 
from the interaction perspective. Here the indicators were, for the managers, the leadership indices, and, for the other employees, the interaction indices. The indices mentioned before include both the cornerstones of deep lead (inspirational motivation, trust, intellectual stimulation, individual consideration) as well as professional skills. The leadership profiles were improved by the management by $4.23 \%$, and other personnel improved their interaction index by $5.16 \%$. The overall growth in turnover was over 16 per cent, which is an excellent figure during a recession. The turnover can surely be raised to the detriment of the sales margin. All together the sales margin grew by 17.45 percent, which is an outright improvement. Earlier, TAC shared a deep leadership culture within the work community, but even so a passive culture was reflected to customers. Concretely this became apparent in a way that customers could not reach a mechanic they had received service from, nor did they get the information of the operations TAC representatives had performed. After the coaching process this seems to have changed in statistical significant way. Regional differences have appeared, and therefore it can be stated that it would be reasonable to also analyze subcultures and the backgrounds of the different factors found in them in different places of business around Finland.

Based on all the results mentioned before, it seems that the changes noticed within both PVO-Vesivoima and TAC (immediate and mediate effects) were also reflected outside of the company (reflection and interest group effects). In light of the research results, the circular idea works as the metaphor by Ahoniemi and Kulmala (2008) about the stone that is thrown into the water about the coaching effectiveness. If a big change takes place in the centre, it is probable that the big change goes further like the waves around the stone thrown into the water. Among the results considered now, it was discovered that significant changes were seen in the immediate effects (e.g.360 evaluation). Considering the mediate effects in the work climate survey, an extensive development towards better results occurred according to different indicators. Some work communities might settle for a situation where the results in work climate survey improve in some areas compared to the previous time. All this is coaching effectiveness which is seen within the work community as changes in interaction between individuals and as changes in cooperation. Without a customer, there would be no service provider, and therefore the effectiveness should be considered from outside the work community to enrich the work community. When other people perceive 
the significant changes, it can be stated that the changes in the operational culture in the work community are seen, reflected, and they also have an effect on the people and different parties outside it. It seems that you can use the coaching / training effectiveness model (figure 2) in studying and also in reporting the research results. There should be a strong correlation between the levels if the leadership coaching / training is effective.

\section{Discussion}

One affecting factor in the leadership coaching / training or other educational intervention is the whole work community being coached, or parts of it. In this study, the two work communities, PVO-Vesivoima and TAC, that took part in the coaching were not crisis organisations, but communities that were already very functional even before coaching (see, for example, the high degree of staff commitment at PVO-Vesivoima in the atmosphere study conducted in 2006, or TAC's baseline levels). It is likely that the lowest levels of Maslow's (1954) hierarchy of needs were saturated among the participants so it was easier to direct the resources to meet the needs of self development. Currently, many working communities are going through a severe restructuring by cooperation negotiations. The security of several (including economic subsistence) might be under threat, and resources may be directed to securing their own job situation. Under such circumstance, coaching processes / educational interventions may not achieve such good results from the perspective of effectiveness, since the learning opportunities of the participants' are significantly disturbed. This is the main idea on how Maslow's hierarchy of needs can be reflected towards personal and work community development. It seems that it is best for both the buyer's interests as well as the interest of the service provider, that there is no attempt to use such a coaching process / educational intervention, which is unable to meet the needs of the work community, in a crisis (or at any other time). We cannot make the changes on other people's behalf, and therefore it would be responsible on behalf of the employer to ensure that there is a positive learning environment for development. An interesting question arises: what kind of coaching effectiveness results would have emerged in this study if the organisations participating in the coaching would have been so-called crisis organisations. 
When the research results in this article were considered as a whole with both PVO-Vesivoima and TAC, the coaching effectiveness results were parallel to the results in the study completed by Ahoniemi and Kulmala (2008; Ahoniemi \& Rytövuori \& Kulmala, 2007; Kulmala \& Ahoniemi $\&$ Nissinen, 2009). Their studies indicated that through Deep Leadership ${ }^{\circledR}$ coaching, work well-being, work climate, information flow, management, comfort and commitment to work improved. Findings of this study indicate that Deep Leadership ${ }^{\circledR}$ coaching had very similar effects in PVO- Vesivoima during the examination periods. The changes were considered significant by various indicators (t-test 360-profile changes, climate survey etc.), and therefore such great changes can be interpreted to be attributed, at least in part, to the coaching process and the related procedures. It is probably safe to say that in this study, coaching was seen as an investment for PVO-Vesivoima, because its benefits were verified both inside and outside the work community. One of the points of view in the coaching effectiveness is that the coaching process raises continuous change in the work community (e.g. Engeström $\&$ Kerosuo \& Kajamaa, 2008). The considered coaching entirety raised, for example, the following practices from the perspective of continuity in PVO-Vesivoima: an active feedback culture (e.g. regularly collected feedback from everyone through 360 evaluates which turned into developmental plans, and which were then used in the annual development discussions held between superiors and subordinates); interaction day when the total result of all the profiles in the work community were examined and the practical operations concerning these were discussed; common rules guiding the operations, and an active interaction and cooperation culture (helping others and sharing more knowledge and know-how). The central outcome of Nikkanen's (2011) effectiveness study was precisely related to strengthening the feedback culture, the continuous practice of the PVO-Vesivoima, which will have a significant impact on the actions of people at all levels. Inadequate feedback culture can have devastating effects in a work community. According to the research conducted by Kinnunen (2007), every leader needs feedback to increase their self-knowledge. Good self-awareness may lead into going deeper into the person's own behaviour, and creating guidelines for how to change leadership behaviour in the future.

There are many factors behind TAC's positive research results. The Deep Leadership ${ }^{\circledR}$ coaching process contributed to strengthening the interaction and management culture. Positive changes in interaction could 
be seen as direct improvements in the 360 profiles. In the overall results, the improvements were statistically significant in each dimension. This, in turn, was reflected in customer satisfaction in such a way that a remarkable overall improvement was achieved compared to the situation before the coaching process. Improvements in know-how in the 360 evaluations were highly significant in the t-test (the dimension of professional skills included an evaluation of a person's professional skills in his / her work tasks and general professional skills in different interactive situations). Also, according to the customer satisfaction survey, the change in the professional skills was significant. The improved customer service, in turn, yielded a better economical performance (rises in turnover and gross margin). Clear indicators are needed to verify the achieved goals, and this time the research work was facilitated significantly by TAC's own (measurement) data.

The research results of this article are presented with the structure of the effectiveness levels -model (figure 2) by Kinnunen and Nissinen (2009; Kinnunen, 2010A \& 2010B). The levels seem to correlate with each other so that often the excellent results in the inner circle levels reflect excellent results at the levels of the outer ring. Thus, the model indicates coaching effectiveness in a way that a good or bad result in the beginning also reflects as a corresponding end result on a wider scale. The results offered by the model can probably be exploited to predict at a very early stage the direction and intensity of the coaching effectiveness. As a whole, the results of PVO-Vesivoima and TAC Services have improved significantly, and the objectives set for the coaching process were accomplished.

Figure 3 represents a model (Kinnunen, 2010A \& 2010B) in which coaching / training or other educational intervention effectiveness is joined with Säljön's and Marton's (1976) concepts of deep and superficial learning and with Nissinen's $(2004,2008)$ framework for interaction behaviour. Engeström, Kerosuo and Kajamaa (2008) have used continuity and discontinuity as central concepts of causal studies. In the figure, these concepts are used to define frames for when the effectiveness can be used to describe a performance. Superficial learning does not lead to a long-term change in human behaviour or thinking, and therefore the phenomena can be described as discontinuous from the perspective of change and learning. In this case, coaching effectiveness does not occur. The same phenomena can be seen in people's reactions: 
"This is nothing new." Coaching will often include elements that are at least partly familiar to the participants from before. This might affect individual learning attitudes in a negative way and prevent long-term changes in their personal behaviour, and in this way hinder coaching effectiveness. At its best, deep learning can help to achieve permanent changes in behaviour when applied in practice. This leads to long-term change in individual thinking and behaviour. The feedback received from the effects of the different behaviour starts a new circle in growth and development, which, by purpose, has been described as the symbol of infinity with no beginning or end $(\infty)$. When permanent practices are formed in groups through individuals and finally the whole work environment, the phenomenon can be described as continuous. These are the conditions for the coaching effectiveness to actualize when defining whether the phenomenon is derived from the coaching process or would have been formed in any case. To make a statement, multiple independent and valid indicators are required to make the final analysis on the effectiveness of a coaching process. The factors that bring about permanent practices or that can be used for forming and confirming continuity can be defined by using valid indicators.

\section{DISCOUNTINUITY: NO EFFECTIVENESS} (SUPERFICIAL LEARMING)

\section{NO EFFECTIVENESS: -coaching offers "nothing new" (learned is not applied) -superficial learning occurs among the participants, quickly forgotten -no permanent continuous practices are formed among the individuals or the work community -the development is restricted to the coaching day}

\section{OCCURRING EFFECTIVENESS:} -tenets of the coaching process are applied in practice at different contents -deep learning happens among the participants, which changes the behavior permanently -continuous practices are formed among the individuals or the work community (for example feedback culture by 360 evaluations) -lifelong development continues $(\infty)$ and appears to other people in different contexts

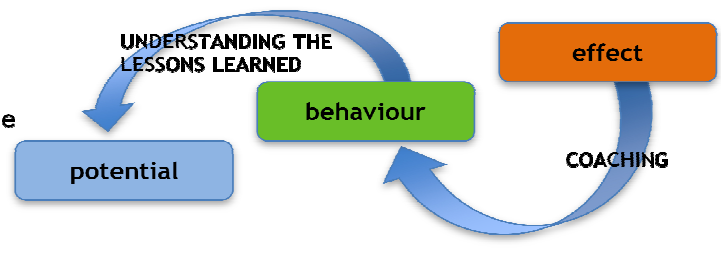

CONTINUITY: EFFECTIVENESS (DEEP LEARNING)

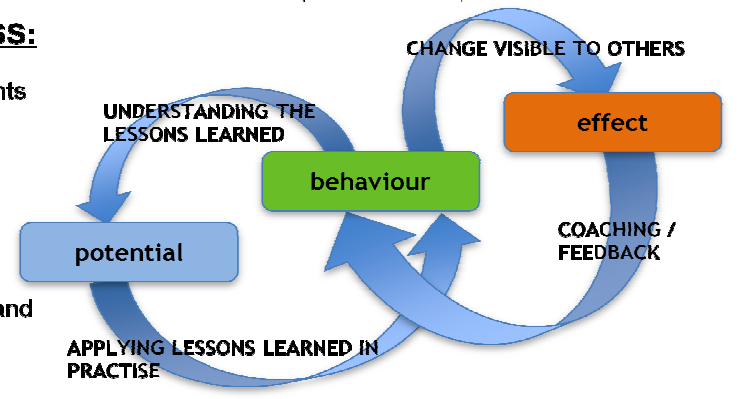

Figure 3. Manifestation of the coaching effectiveness (Kinnunen 2010A \& 2010B) 
The purpose of the Deep Lead ${ }^{\circledR}$ coaching process is to lead people from coaching-led to self-determined change. This is seen when, during the coaching process, the participants are challenged to consider their behaviour and the efficient factors by using different methods. During and after the coaching, an individual will be fusing the lessons learned associating them with their own experiences. If the person is not encouraged to internalise the lessons learned in practice through learning assignments or by other means, there will be no change in their behaviour. As time passes, the lessons learned will be forgotten and the materials of the coaching process will stay untouched. When the person is encouraged to apply what they have learned in practice through assignments or other ways, the lessons learned will transfer into the behaviour of the individual in time. Other people will only see the coaching effectiveness through the changed behaviour in different situations. The changed behaviour, in turn, leads to reflection effects in other people that are different from previous times. At its best, this leads to feedback from others about the renewed behaviour, which, in turn, to the individuals that have changed their behaviour, gives more understanding about the suitability of the lessons learned in coaching to his / her occupational environment. This positive feedback reinforces behaviour according to the experiences, and by means of critical feedback, the person can think of varying ways for applying what they have learned. After this, the person can apply their renewed behaviour, and this is how individual development and growth becomes life-long. A coaching process / educational intervention, and feedback from others, function as inputs for new rounds of improvement.

It is very challenging to confirm the effects of a leadership coaching / training process or other educational intervention on human behaviour, and no researcher has succeeded in overcoming this problem entirely. The individual uniqueness of the human being and the changing occupational environments create a starting point that is unique for the participant and that can never be perfectly reproduced. In addition, the complexity of coaching subjects as well as the personalities and abilities of those coaching make the situation even more complicated. No wonder researchers are doomed to sleepless nights. In this article two contributing models were introduced (figures 2 and 3 ) for examining coaching or training effectiveness. These models can hopefully be used in the future to assess whether the coaching / training process remains to be 
a cost, or whether they are essential investments for the work community. This would be vital information for organisations around the world because during a challenging economical situation it is important that with good leadership organisation can keep up people wellbeing as well as their productivity. More research is needed on how leadership coaching / training can - and will - influence daily work.

\section{References}

Ahoniemi, L. \& Kulmala, H. 2008. Esimiesvalmennus on kannattava investointi (In: Nissinen, V. \& Anttalainen, J. \& Kauppinen, R. 2008. Sovella syväjohtamista - huipputuloksiin vuorovaikutusta oppimalla. Jyväskylä: Gummerus Kirjapaino Oy.)

Engeström, Y. \& Kerosuo, H. \& Kajamaa, A. 2008. Vaikuttavuuden arvioinnista seuraamusten tutkimiseen. (In: Mäkitalo, J. \& Turunen, J. \& Vilkkumaa, I. (edit). 2008. Vaikuttavuus muutoksessa. Oulu: Kalevaprint Oy.)

Kinnunen, T. 2006. Työnohjauksella syvyyttä sotilasjohtamiseen (In: Huhtinen, A. \& Rantapelkonen, J. (edit). 2006. Sirpaleita sotilaskulttuurin rajoilta. Maanpuolustuskorkeakoulu; johtamisen laitoksen julkaisusarja 2, artikkelikokoelmat n:o 17, 2006. Helsinki: Edita Prima Oy)

Kinnunen, T. 2007. Suomalaisen johtajan 360-profiili (In: Tiede ja Ase. Suomen sotatieteellisen seuran vuosijulkaisu N:o 65, 2007. Vaasa: Waasa Graphics.)

Kinnunen, T. 2008. Syväjohtamisen malli työnohjauksen työkaluna ja päinvastoin. (In: Nissinen, V. \& Anttalainen, J. \& Kauppinen, R. 2008. Sovella syväjohtamista - huipputuloksiin vuorovaikutusta oppimalla. Jyväskylä: Gummerus Kirjapaino Oy.)

Kinnunen, T. 2009. Esimiesvalmennus ja syväjohtaminen. (In: Kiuru, J. (toim). 2009. Johdatus johtamiseen. Maanpuolustuskorkeakoulu; johtamisen ja sotilaspedagogiikan laitoksen julkaisusarja 2, artikkelikokoelmat n:o 3, 2009. Helsinki: Edita Prima Oy).

Kirkpatrick, D.L. 1998. Evaluating Training Programs: The Four Levels. 2. renewed edition. San Francisco: Berrett-Koehler Publishers.

Kulmala, H. \& Ahoniemi, L. \& Nissinen, V. 2009. Performance Through Measuring Leader's Profiles: An Empirical Study. International Journal of Production Economics, 2009, vol. 122, issue 1, pages 385-394.

Marton, F. \& Säljö, R. 1976. On Qualitative Differences in learning I: Outcome and Process. British Journal of Educational Psychology, 46, 4-11.

Maslow, A. 1954. Motivation and Personality. Universal Container Corporation, Second edition.

Mäkitalo, J. \& Turunen, J. \& Vilkkumaa, I. (edit). 2008. Vaikuttavuus muutoksessa. Oulu: Kalevaprint Oy.

Nikkanen, J. 2011. Akateeminen johtajuus muutoksessa - tutkimus Helsingin yliopiston ylimmän johdon esimies- ja vuorovaikutusvalmennuksesta. Helsingin yliopiston hallinnon julkaisuja 74; raportit ja selvitykset.

Nissinen, V. 2004. Syväjohtaminen. Helsinki: Talentum. 
Nissinen, V. 2008. Kohti syväjohtamisen vaikuttavuusohjelmaa (Teoksessa: Nissinen, V. \& Anttalainen, J. \& Kauppinen, R. 2008. Sovella syväjohtamista huipputuloksiin vuorovaikutusta oppimalla. Jyväskylä: Gummerus Kirjapaino Oy.)

Westley, C. 2005. Exploring the Effectiveness of Leadership Training on Adult Learners: An Evaluation of the Leadership and Communications workshop for Natural Resource Professionals. Master thesis, The University of Alaska Anchorage.

\section{Unpublished references}

Ahoniemi, L. \& Rytövuori, S. \& Kulmala, H. 2007. Lähiesimiesvalmennuksen vaikuttavuuden arviointi työilmapiiritutkimustulosten, 360 asteen johtajaprofiilien ja taloudellisten tunnuslukujen avulla. Loppuraportti tutkimustuloksista heinäkuu 2007. Tampereen yliopiston kauppakorkeakoulu.

The Internet interview of Birger Ylisaukko-oja 2010 (PVO-Vesivoima Oy:n toimitusjohtaja avasi yksityiskohtaisemmin valmennuksen tarpeita sekä näkemyksiään, mitkä tekijät ovat vaikuttaneet yhtiön toimintatavan muutokseen).

DL. 2010. Deep Lead Oy:n valmennusmateriaalit vuosilta 2007-2010. (The coaching materials of the Deep Lead Oy from the years 2007-2010.)

Kiljunen, P. 2009. Vesivoiman käyttö ja Pohjolan Voima. Tutkimus PVOVesivoima Oy:n yrityskuvasta ja energiapoliittisista näkemyksistä yhtiön toimintaympäristössä. Yhdyskuntatutkimus Oy, raportti 22.09.2009.

Kinnunen, T. \& Nissinen, V. 2009. Vaikuttavuuden tarkastelua. Deep Lead Oy:n vaikuttavuusmateriaali. (The effectiveness materials of the Deep Lead Oy.)

Kinnunen. T. 2010A. Yhteistyöllä työyhteisö menestykseen - valmennuksen vaikuttavuuden tarkastelua. (case: PVO-Vesivoima Oy)

Kinnunen. T. 2010B. Vuorovaikutuksella asiakastyytyväisyyteen valmennuksen vaikuttavuuden tarkastelua. (case: TAC Finland Oy Service)

PVO-Vesivoima Oy:n Työilmapiiritutkimus vuodelta 2006. (The work climate survey of the PVO Vesivoima from the year 2006.)

PVO-Vesivoima Oy:n Työilmapiiritutkimus vuodelta 2008. (The work climate survey of the PVO Vesivoima from the year 2008.)

PVO-Vesivoima Oy:n profiilien tulokset vuosilta 2007-2009. (The profile results of the PVO Vesivoima from the years 2007-2009)

Schneider Electric: OneVoice henkilöstökyselyn tulokset vuodelta 2009: Q2+Q3+Q4, 2010 (The results of the OneVoice personnel survey from the year 2009)

TAC Finland Oy Servicen profiilien tulokset vuosilta 2008-2009. (The profile results of the TAC Finland Oy Service from the years 2008-2009)

TAC Finland Oy:n huolto-organisaation asiakastyytyväisyystutkimus.

Yhteenveto 8.6.2009. Mercuri International. (The customer satisfaction survey of the maintenance organisation of the TAC Finland Oy. Summary on June $8^{\text {th }} 2009$. Mercuri International.)

TAC Finland Oy:n huolto-organisaation tulosvertailu 2008-2009, 2010 (Outcomes)

TAC Finland Oy:n huolto-organisaation vuosivertailut 2005-2009, 2010 (Annuals)

TAC Finland Oy:n PeopleScope -henkilöstön työtyytyväisyyskysely 2008 (Work climate survey)

TAC Finland Oy:n tuntikirjanpito sairaspoissaoloista 6/2007 - 2/2010 (Sickleaves) 